\title{
The Development and Implementation of Learning Objects in a Higher Education Setting
}

\author{
Kristy de Salas and Leonie Ellis \\ School of Information Systems, University of Tasmania, \\ Hobart, Tasmania, Australia
}

\author{
Kristy.deSalas@utas.edu.au Leonie.Ellis@utas.edu.au
}

\begin{abstract}
With the increase in offshore and off-campus demand for University of Tasmania degrees, lecturers have become aware of the need to develop more flexible delivery processes which add value to the student learning experience and provide teaching staff with opportunities for greater creativity in the teaching process. The three cases described will outline a model guiding Learning Object development and teaching within the School of Information Systems and will describe the process of student interaction and response to these Learning Objects. This paper describes the replacement of face-to-face lectures with the online delivery of complex learning objects, resulting in high quality outcomes for students. The development of these discrete re-usable learning objects has followed a 'tell, show and do' model by way of integrating a theory presentation with a practical example exercise, followed by an opportunity for individual review \& application of the material within each learning object. The development of these Learning objects has been undertaken in Microsoft ${ }^{\circledR}$ Office PowerPoint ${ }^{\circledR}$ with audio narration, with files being compressed using Impatica for PowerPoint ${ }^{\mathrm{TM}}$ and streamed within the University environment by WebCT Vista allowing access to all students enrolled over three local campuses as well as those enrolled interstate and overseas. The application and use of these learning objects has allowed for the concentration of face-to-face resources on highly interactive workshops that are supported by the Learning Objects, rather than on traditional lectures. The outcomes are better coverage of material in the three units, greater student satisfaction with the delivery of the unit and increased flexibility for both the students and staff.
\end{abstract}

Keywords: Learning Objects, higher education, curriculum design, online learning, flexible delivery

\section{Introduction}

Since the early 2000s, the University of Tasmania has recognised the importance of flexibility in its teaching and learning approaches. Flexibility is important in a higher education setting as:

Material published as part of this journal, either on-line or in print, is copyrighted by the Informing Science Institute. Permission to make digital or paper copy of part or all of these works for personal or classroom use is granted without fee provided that the copies are not made or distributed for profit or commercial advantage AND that copies 1) bear this notice in full and 2) give the full citation on the first page. It is permissible to abstract these works so long as credit is given. To copy in all other cases or to republish or to post on a server or to redistribute to lists requires specific permission and payment of a fee. Contact Publisher@InformingScience.org to request redistribution permission.
- all organisations are being called upon to become more flexible in response to a range of contemporary demands;

- flexible approaches to teaching and learning provide the potential to attract more students;

- $\quad$ students expect to learn about ICT within the discipline they are studying; and 
- arrangements to teach cohorts of students offshore and interstate will be more readily implemented through flexible teaching and learning strategies (Johnston, 2001).

The benefits for students from the implementation of flexible teaching and learning options can be seen in that:

- flexible approaches to teaching and learning cater for students who have work and family commitments, or those who for any reason are unable to attend classes at set times on a regular basis;

- flexible approaches to teaching and learning cater for a range of student learning styles and approaches;

- $\quad$ students are given more choices about how, when, and where they learn; and

- flexible approaches to teaching and learning can be used to facilitate workplace learning, professional practice and other off-campus experiences for students (Johnston, 2001).

While there are considerable benefits for students, it can also be seen that staff within the University environment can also take advantage of the benefits of flexibility in teaching and learning, in that:

- flexible approaches to teaching and learning provide potential for academic workloads to be organised more flexibly;

- teaching across campuses can be accommodated without the necessity to travel on a regular basis;

- there are opportunities to use resource materials that are developed elsewhere; and

- there is potential to establish collaborative or commercial arrangements in which resource materials developed within one university are used in other universities or other teaching situations (Johnston, 2001).

This paper describes and discusses the implementation of Learning Objects as a flexible teaching and learning mechanism within the University of Tasmania. Three final-year units taught within the School of Information Systems were transformed to include Learning Objects as a significant component of their course structure, each unit applying the Learning Objects in a slightly different way:

- BSA306 Electronic Commerce - Learning Objects used to deliver theoretical content and provide opportunities for practical and applied content review in support of face to face workshops;

- BSA303 Management of Information Systems - Learning Objects used to deliver theoretical content and provide opportunities for practical and applied content review, supported by discussion boards and face to face workshops;

- BSA304 Decision Support Systems - Learning Objects used to deliver theoretical content and provide opportunities for practical and applied content review in support of online workshops.

\section{Drivers for the Adoption of Flexible Methods at the University of Tasmania}

Within the University of Tasmania environment it has been recognised that student expectations have become more complex within an increasingly heterogenous student body ( Flexible Educa- 
tion Unit, 2002), and as such increased access through flexible teaching and learning approaches continue to be a strategic priority for the University.

The terms 'flexible teaching and learning' and 'flexible delivery' are now commonly used across the higher education sector and in other educational contexts (Johnston, 2001). While the terms are used in many different ways and associated with many different meanings one useful definition is:

"...flexible approaches to teaching and learning refer both to an educational philosophy and a set of techniques to teaching and learning. The term describes an approach to education that is more a learner-centred and that increases the learner's responsibility for his or her own learning. Flexible approaches increase the degree of student control over when, what, where, how and at what pace they learn. These include approaches to teaching and learning which are less time and place dependent than more traditional forms of teaching" (Johnston, 2001).

It has been recognised that there is no single way to teach or learn flexibly. With this in mind, there have been many types of strategies for introducing more flexibility within courses at the University of Tasmania including: videoconferencing and audio conferencing, flexible scheduling, flexible pathways, workplace learning, resource-based teaching and online teaching (Flexible Education Unit, 2002).

With this University-wide strategic emphasis on flexibility, it has become expected that Faculties and Schools will identify priorities for implementing flexibility within their own teaching and learning practices. This expectation has led Faculties and Schools to become committed to the development of student-centred, flexible teaching and learning and to developing a level of expertise among staff in the design and development of teaching modules that demonstrate best practice in the utilisation of technology for the delivery of tertiary units (Commerce, 2003).

It is within this environment of teaching and learning innovation that two academics of the School of Information Systems were awarded small teaching development grants to investigate and trial new styles of online delivery and learning, specifically the development of Learning Objects, within three final-year Information Systems units.

\section{Learning Objects: Some Background}

\section{What are Learning Objects?}

The concept of Learning Objects is grounded in the object-oriented paradigm of computer science (Freeman, 2004). The principle of Learning Objects is the creation of instructional components that can be reused numerous times in different learning contexts.

According to Gallenson, Heins, \& Heins (2002), a Learning Object is a unit of instructionally sound content centred on a learning objective or outcome intended to teach a focused concept. It is a fundamental building block composed of all the instructionally necessary components to comprise a self-contained instructional unit. These multimedia learning materials as described by Hiddink (2001), EDUCAUSE (2005), and Gallenson et al. (2002) include, but are not limited to, simulations, electronic calculations, animations, tutorials, text entries, web sites, bibliographies, audio and video clips, quizzes, photographs, illustrations, diagrams, grafts, maps, charts, and assessments combined for the purpose of presenting interchangeable examples, arguments, cases, and practical exercises, which can be instructor guided or based on learner self-interest and selfdetermined need (Parrish, 2004).

Learning Objects vary in size, scope, and level of granularity ranging from a small chunk of instruction to a series of resources combined to provide a more complex learning experience 
(EDUCAUSE, 2005). This is a new way of looking at curriculum in which content is broken up into discrete pieces or Learning Objects. Teachers and learners then go about the process of creating linkages between chunks in order to construct understanding (Polsani, 2003).

These Learning Objects can be delivered over the Internet and can be accessed by a number of individuals simultaneously, with minimal effort, reducing the need for instructors to develop their own instructional components. They allow for increased speed and efficiency of instructional development and decrease faculty preparation time (Freeman, 2004).

\section{Benefits of Learning Objects}

According to Wiley (2000), the fundamental idea behind Learning Objects is that instructional designers can build small instructional components that can be reused a number of times in different learning contexts. Additionally, Learning Objects are generally understood to be digital entities deliverable over the Internet, meaning that any number of people can access and use them simultaneously.

This new mode of content development and delivery can be used to play a supporting role with instruction that supports active learning strategies (Parrish, 2004). Since their inception, Learning Objects have been seen as capable of fostering effective learning by introducing active learning experiences, supporting student-centred learning environments, propagating new ideas about instruction, and increasing collaboration and sharing of resources, it can play a major role in improving education and training (Parrish, 2004).

\section{Benefits to learners}

- Learning Objects allow the creation of highly effective learning experiences for students (Parrish 2004) and enhancing the student learning environment (EDUCAUSE, 2005);

- The choice of which Learning Objects to assemble into all collection can be a decision made in advance by an instructional designer or at the moment by a student;

- Learning Objects allow experiences in problem-solving and exploration and collaboration with fellow learners;

- Learning Objects allow universal access to online instructional materials (Parrish, 2004); and

- Learning Objects provide solutions for individualising learning (Parrish, 2004)

\section{Benefits for developers/instructors}

- Learning Objects are highly interoperable and reusable modular building blocks or elearning content based on widely shared specifications (Clyde, 2004);

- Learning Objects promote better collaboration among developers (Parrish, 2004);

- Learning Objects provide resources for instruction where they might not otherwise (Parrish, 2004);

- Learning Objects can be combined in nearly infinite ways to construct collections that might be called lessons, modules, course or even curricula;

- Learning Objects allow for increased productivity among trainers and educators (Parrish, 2004);

- Learning Objects provide value in terms of saving time and money in course development (EDUCAUSE, 2005); 
- Learning Objects allow for increases in the reusability of content (EDUCAUSE, 2005);

- Learning Objects allow for sharing knowledge within and across disciplines (EDUCAUSE, 2005); and

- Learning Objects engage faculty in a dynamic community of practice (EDUCAUSE, 2005).

\section{The Goals of Learning Object Design}

According to Parrish (2004) Learning Objects could turn out to be an interesting new facet of instructional design practice, and, applied with the right precautions in mind could be the trend that will have the biggest impact on online learning in this decade.

In order to obtain the benefits to be gained from the use of Learning Objects within educational environments, developers should strive for the fulfilment of the following four goals in their developments and implementations:

- Reusability: Learning content should be modularised into small units of instruction suitable for assembly and reassembly into a variety of courses;

- Interoperability: Instructional units should be able to interoperate with each other regardless of developer or learning management system;

- Durability: Units of instruction should be able to withstand ever evolving delivery and presentation technologies without becoming unusable; and

- Accessibility: Learning content should be available anywhere, any time - learning content that can be discovered and reused across networks.

\section{Model of Learning Object Development at the School of Information Systems}

In light of the emphasis on flexible teaching and learning within the higher education sector, staff from the School of Information Systems undertook a preliminary survey of its students to identify their preference for teaching and learning methods and their apparent readiness for the introduction of flexibility in their studies.

The results from this study suggested the following:

- $1^{\text {st }}$ year students preferred face to face content delivery and were most comfortable with a model of a single two-hour face-to-face lecture and a single one-hour interactive workshop per week $(2 \mathrm{~L}+1 \mathrm{~W})$.

- $\quad 2^{\text {nd }}$ year students indicated a readiness for some aspects of flexibility, and preferred less lecturing and more interaction. Their preferred model of teaching and learning was a single one-hour face-to-face lecture and a single two-hour interactive workshop per week $(1 \mathrm{~L}+2 \mathrm{~W})$.

- $\quad 3^{\text {rd }}$ year students indicated a strong preference for greater flexibility in their dealings with the University. While no single method of interaction was preferred by this group, there was a general emphasis towards more online delivery of theoretical content supported by face-to-face interactive workshop sessions.

With the results of this preliminary study in mind, two academics undertook a small-scale flexibility trial in the School of Information Systems. Due to the scale of the trial being conducted within the School, it was determined that small scale innovations in instruction were more appro- 
priate given budget and time constraints than complete curriculum changes (Parrish, 2004). As a result three third-year courses were selected as appropriate for inclusion in the trial given:

- these three courses were at the third-year level of the degree,

- these courses were coordinated by those staff who had received the teaching grants, and

- it was expected that there would be some elements of common content between these units which allowed the reusability concept of Learning Objects to be explored.

BSA306 Electronic Commerce introduces students to the technologies and business processes associated with Electronic Commerce. It covers relevant standards; modes of conducting electronic commerce; commercial issues in the adoption of electronic commerce; relevant business processes and the transformational effects of electronic commerce on these business processes; in addition to social implications and future directions.

BSA303 Management of Information Systems is designed to prepare students to critically analyse business environments and to identify the potential usage for strategic information systems within organisations. This unit introduces the concepts of strategic information systems in a business environment. It examines what is meant by a strategic information system and why they are being used in business. The unit explores the role of an IS manager, the IS function and the development of IS policies.

BSA304 Decision Support Systems is designed to prepare students to critically understand the types of decision support systems used in business, and their respective strengths and limitations. This unit investigates the role that decision support systems can play within organisations to facilitate individual and group decision making.

Prior to this trial, each of these units were delivered according to a traditional model of a single one-hour face to face lecture per week (covering theoretical content), followed by a single twohour workshop per week (covering practical activity-based content), delivered over a thirteenweek period.

The following discussion gives a staged overview of the process of reflection and development in the construct of the Learning Object environment.

\section{Stage 1: Develop Clear Learning Objectives for Each Course}

The importance of clearly defined learning objectives in educational design is widely known. Within the field of Learning Objects, it has also been identified as one of the critical characteristics leading any developments. Johnson, (2003) clearly states that a learning object is not only a collection of digital materials, but a collection of materials coupled with a clear and measurable learning objective or designed to support a learning process.

With this in mind, each course was analysed in order to clearly define its specific learning objectives. Each learning objective was noted and used as a basis to guide all subsequent content development for each course. See Table 1 for an example. 
Table 1: Unit Learning Objectives

\section{Electronic Commerce Learning Objectives}

On completion of this unit, students should:

a) Have knowledge of the technologies, standards and business processes utilised in the implementation of electronic commerce.

b) Understand the current modes of applying information technologies to commercial activities, and the opportunities arising from new developments in inter-organisational systems and consumer acceptance of the Internet.

c) Be aware of the potential for electronic commerce to transform business, and the effect such change can have, on organisations, individuals and society.

d) Be capable of developing a preliminary design for the application of electronic commerce to a particular business area.

e) Be capable of producing professional-style reports and presentation material for various audiences.

\section{Management of Information Systems Learning Objectives}

On completion of this unit, students should:

a) Be capable of developing an IS strategic plan;

b) Be capable of developing a vision and mission statement for an organisation;

c) Have an understanding of the range of skills and knowledge required for IS management;

d) Be capable of critically analysing business case studies or scenarios both individually and in small groups;

e) Be capable of effectively engaging in group problem solving and presentation of appropriate solutions;

f) Be capable of developing and presenting a written IS business case.

\section{Decision Support Systems Learning Objectives}

On completion of this unit, students should:

a) Understand the types of decision support systems used in business, their respective strengths and limitations

b) Understand the roles that decision support systems can play within organisations to facilitate individual and group decision making.

c) Examine and understand the major components of computer-based decision support systems.

d) Analyse and design decision support systems using standard software found in Microsoft Office

\section{Stage 2: Modelled All Existing Content}

Stage 2 of the analysis process required the Unit Coordinators to identify all aspects of the course content that was currently used and any opportunities for new course content to be included. See Table 2 for an example. 
Table 2: Unit sample content maps

\begin{tabular}{|c|c|c|}
\hline \multicolumn{3}{|c|}{ Electronic Commerce sample content map } \\
\hline Existing content topic & Individual Theoretical elements & Individual Practical elements \\
\hline \multirow[t]{3}{*}{$\begin{array}{l}\text { Introduction to Electronic Com- } \\
\text { merce }\end{array}$} & What is Electronic Commerce? & $\begin{array}{l}\text { Case study \& questions - Types } \\
\text { of Ecommerce }\end{array}$ \\
\hline & $\begin{array}{l}\text { Benefits \& Limitations of Elec- } \\
\text { tronic Commerce }\end{array}$ & $\begin{array}{l}\text { Case study \& questions - } \\
\text { Consumers, Business \& Society }\end{array}$ \\
\hline & Myths of Ecommerce & $\begin{array}{l}\text { Case study \& questions - Fact vs } \\
\text { Fiction }\end{array}$ \\
\hline \multirow[t]{3}{*}{$\begin{array}{l}\text { Ecommerce and Organisational } \\
\text { Strategies }\end{array}$} & Organisational strategy & $\begin{array}{l}\text { Case study \& questions - } \\
\text { Organisations and strategic } \\
\text { development }\end{array}$ \\
\hline & $\begin{array}{l}\text { IT enabled organisational strat- } \\
\text { egy } \\
\text { Organisational Analysis }\end{array}$ & $\begin{array}{l}\text { Case study \& questions - IT } \\
\text { enabled strategic advantage }\end{array}$ \\
\hline & Ecommerce Business models & $\begin{array}{l}\text { Case study \& questions - } \\
\text { Ecommerce business models }\end{array}$ \\
\hline \multirow[t]{2}{*}{ Professional Development } & Business report presentation & Development of Business reports \\
\hline & Oral presentation skills & Oral presentation \\
\hline \multicolumn{3}{|c|}{ Management of Information Systems sample content map } \\
\hline Existing content topic & Individual Theoretical elements & Individual Practical elements \\
\hline Competitive Advantage & $\begin{array}{l}\text { Strategic Competitive } \\
\text { Advantage } \\
\text { Strategic Thinking } \\
\text { Strategic Models } \\
\text { IT enabled organisational } \\
\text { strategy }\end{array}$ & $\begin{array}{l}\text { Case study \& questions - } \\
\text { Strategic planning } \\
\text { Creation of a strategic plan } \\
\text { Creation of a strategic plan } \\
\text { Case study \& questions - IT } \\
\text { enabled strategic advantage }\end{array}$ \\
\hline \multirow[t]{2}{*}{ Change Management } & Frameworks for change & $\begin{array}{l}\text { Development of a change man- } \\
\text { agement strategy }\end{array}$ \\
\hline & Leadership and change & $\begin{array}{l}\text { Development of a change } \\
\text { management strategy }\end{array}$ \\
\hline Creative Thinking & Six thinking hats & $\begin{array}{l}\text { Case study \& questions - } \\
\text { creative thinking }\end{array}$ \\
\hline Professional Development & $\begin{array}{l}\text { Business report presentation } \\
\text { Oral presentation skills }\end{array}$ & $\begin{array}{l}\text { Development of Business reports } \\
\text { Oral presentation }\end{array}$ \\
\hline \multicolumn{3}{|c|}{ Decision Support Systems sample content map } \\
\hline Existing content topic & Individual Theoretical elements & Individual Practical elements \\
\hline \multirow[t]{2}{*}{ Systems Perspective } & Information Quality & $\begin{array}{l}\text { Case study \& questions - Assess- } \\
\text { ing and discussing information } \\
\text { quality factors. }\end{array}$ \\
\hline & Information Quality Factors & $\begin{array}{l}\text { Case study \& questions - } \\
\text { Constructing Service Level } \\
\text { Agreements }\end{array}$ \\
\hline Sensitivity Analysis & $\begin{array}{l}\text { Single Variable Analysis } \\
\text { Multiple Variable Analysis }\end{array}$ & $\begin{array}{l}\text { Sensitivity Analysis of Models } \\
\text { Sensitivity Analysis of Models }\end{array}$ \\
\hline $\begin{array}{l}\text { Creative Decision Making \& } \\
\text { Problem Solving }\end{array}$ & Six thinking hats & $\begin{array}{l}\text { Case study \& questions - } \\
\text { creative thinking }\end{array}$ \\
\hline
\end{tabular}




\section{Stage 3: Split All Existing Content into Discrete Objects}

As reusable Learning Objects can be seen as information 'chunks' (Polsani, 2003), stage 3 of the Learning Objects development process followed that all course content, as identified in stage 2, was broken down into individual topic-specific components. This follows the strong leaning towards the notion that people should learn small amounts of discrete information at one time and slowly build a network of these information chunks (Orrill, 2000), therefore an object may teach a single process or idea. See Table 3 for an example.

Table 3: Unit topic-specific components

\begin{tabular}{|l|l|l|}
\hline \multicolumn{1}{|c|}{$\begin{array}{c}\text { Electronic Commerce } \\
\text { Topic-specific components }\end{array}$} & $\begin{array}{c}\text { Management of Information } \\
\text { Systems Topic-specific compo- } \\
\text { nents }\end{array}$ & $\begin{array}{c}\text { Decision Support Systems } \\
\text { Topic-specific components }\end{array}$ \\
\hline What is Electronic Commerce? & Strategic Competitive Advantage & Information Quality \\
\hline $\begin{array}{l}\text { Benefits \& Limitations of Elec- } \\
\text { tronic Commerce }\end{array}$ & Strategic Thinking & Information Quality Factors \\
\hline Myths of Ecommerce & Strategic Models & Single Variable Analysis \\
\hline Organisational strategy & IT enabled organisational strategy & Multiple Variable Analysis \\
\hline $\begin{array}{l}\text { IT enabled organisational strat- } \\
\text { egy }\end{array}$ & Frameworks for change & Six thinking hats \\
\hline Organisational Analysis & Leadership and change & Components of DSS \\
\hline Ecommerce Business models & Six thinking hats & What is an Expert System \\
\hline Business report presentation & Business report presentation & Inference Engines \\
\hline Oral presentation skills & Oral presentation skills & What is a Decision Tree \\
\hline Tools for Information security & What is Outsourcing & GDSS components \\
\hline Legal Issues for Ecommerce & Organisational Analysis & What is Groupware \\
\hline
\end{tabular}

\section{Stage 4: Identified Common Elements of Content across Courses}

As the underlying tenet of the Learning Object design is reusability, all learning content should be modularised into small units of instruction for assembly and reassembly into a variety of courses (Parrish, 2004).

At the completion of breaking down each topic into its most basic element, as described in stage 3 , those lecturers involved in the trial development reviewed the lists of topic-specific components from each course. While each course was developed independently and was designed to fulfil its own specific learning objectives, it became clear that there existed some level of course development repetition as many of the core topics were common across units, but had previously been developed and delivered by three separate academics at the same time. See Table 4 for an example. 
Table 4: Common components across Units

\begin{tabular}{|c|c|c|}
\hline $\begin{array}{c}\text { Electronic Commerce } \\
\text { Topic-specific components }\end{array}$ & $\begin{array}{l}\text { Management of Information } \\
\text { Systems Topic-specific } \\
\text { components }\end{array}$ & $\begin{array}{l}\text { Decision Support Systems } \\
\text { Topic-specific components }\end{array}$ \\
\hline What is Electronic Commerce? & Strategic Competitive Advantage & Information Quality \\
\hline $\begin{array}{l}\text { Benefits \& Limitations of Elec- } \\
\text { tronic Commerce }\end{array}$ & Strategic Thinking & Information Quality Factors \\
\hline Myths of Ecommerce & Strategic Models & Single Variable Analysis \\
\hline $\begin{array}{l}\text { IT enabled organisational } \\
\text { strategy }\end{array}$ & $\begin{array}{l}\text { IT enabled organisational strat- } \\
\text { egy }\end{array}$ & Multiple Variable Analysis \\
\hline Organisational Analysis & Organisational Analysis & What is an Expert System \\
\hline Ecommerce Business models & Leadership and change & Components of DSS \\
\hline Tools for Information security & Six thinking hats & Six thinking hats \\
\hline Business report presentation & Business report presentation & Inference Engines \\
\hline Oral presentation skills & Oral presentation skills & What is a Decision Tree \\
\hline Organisational strategy & What is Outsourcing & GDSS components \\
\hline Legal Issues for Ecommerce & Frameworks for change & What is Groupware \\
\hline
\end{tabular}

In order to overcome the redundancy associated with traditional course material development, it was now important to compile a list of all discrete content topics that were required for the three courses. See Table 5 for an example.

Table 5: Sample of Discrete Content Topics from all Units

\begin{tabular}{|l|l|}
\hline What is Electronic Commerce? & Leadership and change \\
\hline $\begin{array}{l}\text { Benefits \& Limitations of Electronic } \\
\text { Commerce }\end{array}$ & Six thinking hats \\
\hline Myths of Ecommerce & What is Outsourcing \\
\hline IT enabled organisational strategy & Frameworks for change \\
\hline Organisational Analysis & Information Quality \\
\hline Ecommerce Business models & Information Quality Factors \\
\hline Tools for Information security & Single Variable Analysis \\
\hline Business report presentation & Multiple Variable Analysis \\
\hline Oral presentation skills & What is an Expert System \\
\hline Organisational strategy & Components of DSS \\
\hline Legal Issues for Ecommerce & Inference Engines \\
\hline Strategic Competitive Advantage & What is a Decision Tree \\
\hline Strategic Thinking & GDSS components \\
\hline Strategic Models & What is Groupware \\
\hline
\end{tabular}


Once the individual core topic components were identified, it followed that each topic was then developed into a discrete Learning Object.

\section{Stage 5: Development of a Learning Object for Each Discrete Content Element (TELL, SHOW, DO)}

When developing Learning Objects, it becomes clear that there is no standard way of developing these objects and that Learning Objects can come in many forms. Following the principle that information may be more readily learned if learners have access to it in multiple presentation modes, it was decided that each learning object, while being discrete and separate from the next, would include multiple learning options within its boundaries.

Each learning object was designed with three interconnected aims (see Figure 1):

- To provide theoretical content on a specific topic (TELL);

- To provide examples of how the theoretical content could be applied (SHOW); and

- To provide an opportunity for students to apply the theoretical content to a real-world situation (DO).

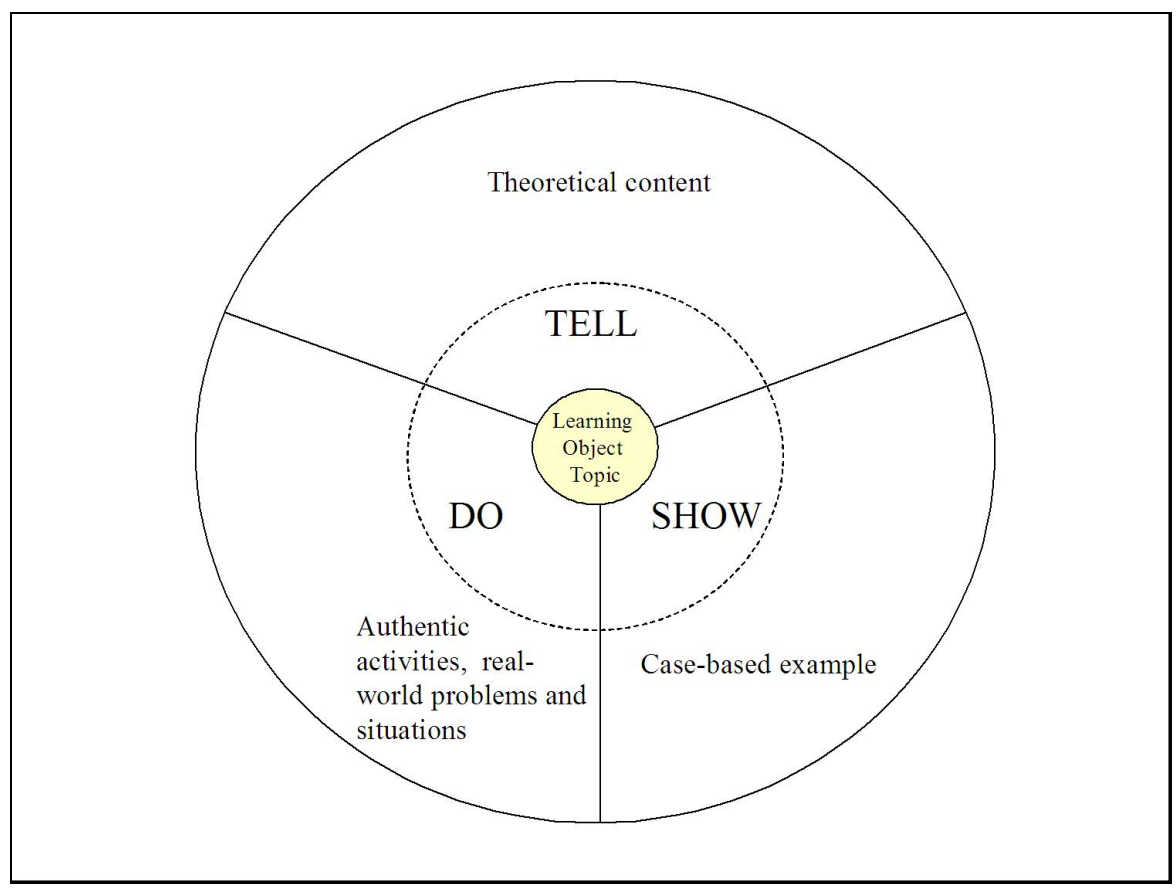

Figure 1: Learning Object design model

See Table 6 for an example.

Table 6: Learning Object design for sample topic

Learning Object Topic $\rightarrow$ Organisational Analysis

- Theoretical Content (TELL) $\rightarrow$ Purpose of organisational analysis

- Case-based Example (SHOW) $\rightarrow$ Examples of the application of tools used to assist in the analysis process

- Real-world problem (DO) $\rightarrow$ Students required to undertake an organisational analysis of a given context. 


\section{Technological characteristics of the learning object development}

According to Clyde (2004) simplicity and standardisation is of high priority when constructing Learning Objects. The tools needed for the development of these objects need to be operable across different types of computers and software, and they need to be able to interact with other tools if digital content and courseware is to be used across a range of technology platforms. In order to ensure that the Learning Objects being created were easily accessible and platform independent, it was decided that a simplistic technological approach to the development of each object was necessary.

In ensuring that the learning content would be available anywhere, any time and could be reused across networks authoring tools (Parrish, 2004), it was necessary to determine whether to adopt simplicity for students or adopt more sophisticated tools. This complexity versus usability tradeoff led to the choice of a number of easily available applications being selected as the technological basis for the Learning Object creation. Figure 2 provides a graphical illustration of the elements of the technological development.

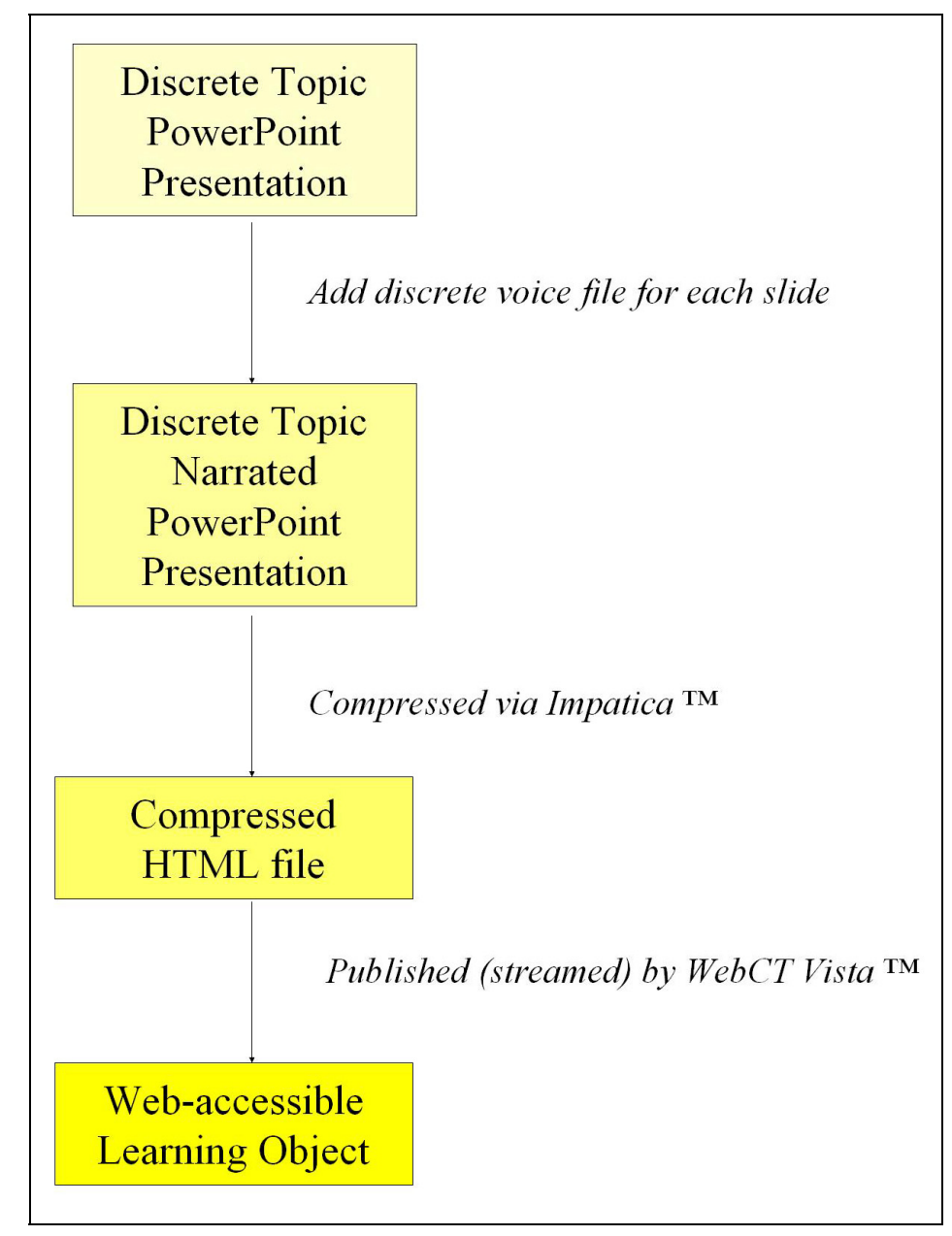

Figure 2: Technological characteristics of the Learning Object 


\section{Discrete topic PowerPoint ${ }^{\circ}$ presentation}

As an initial step, learning object topics were developed using Microsoft ${ }^{\circledR}$ Office PowerPoint ${ }^{\circledR}$. All theoretical content for each topic was developed in the form of 5-8 presentation slides (see Figure 3).

\section{Discrete Topic Narrated PowerPoint ${ }^{\circledR}$ Presentation}

Following the creation of each slide, an audio file was recorded providing expert narration of the slide content. Each audio file was then attached to the corresponding slide. The individual recording of each slide was deemed necessary as it allowed for the possibility of each Learning Object to be augmented by individual lecturers if necessary, thus increasing its reusability across courses (see Figure 4).
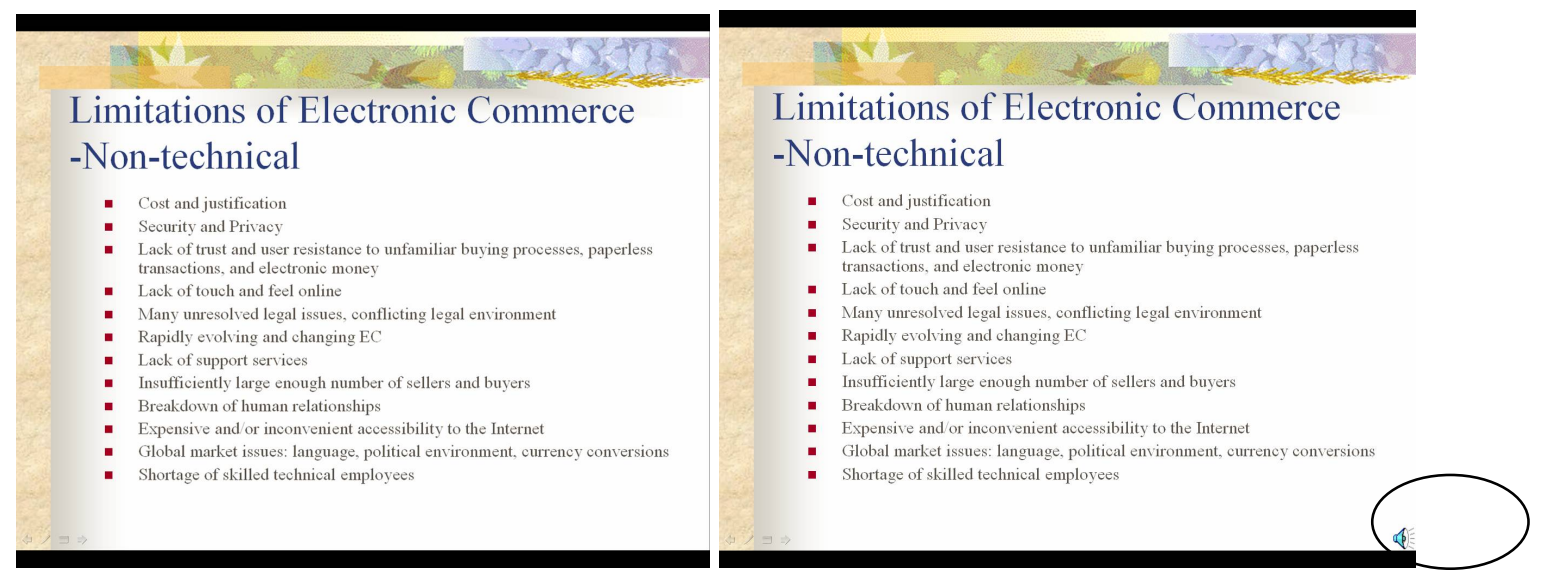

Figure 3: Discrete PowerPoint ${ }^{\circledR}$ slide $\quad$ Figure 4: Discrete PowerPoint ${ }^{\circledR}$ slide with narration

\section{Compressed HTML file}

Once each Learning Object had been created in a PowerPoint ${ }^{\circledR}$ presentation, these files were then converted into compressed HTML, but way of Impatica for PowerPoint ${ }^{\mathrm{TM}}$. This software application was chosen as it enabled the compression by $1 / 8^{\text {th }}$ of the original file size and fulfilled the trial's requirement of small file size to facilitate the delivery of web-streamed content.

\section{Web accessible learning object}

Because the objective of the Learning Object development process was to provide students with access to more flexible Teaching and Learning environments, it was necessary to investigate options for making these objects easily available via the Internet. Prior to the undertaking of this trial project, WebCT Vista had been chosen as the centrally supported courseware tool for online teaching at the University of Tasmania. WebCT Vista enabled students to access information, course content, and news updates via the Web. As a result of this implementation, the most logical publishing mechanism was through the use of this courseware tool.

\section{Stage 6: Course Construction}

The purpose of Learning Objects is to enable course designers to choose from available materials and to construct an educational environment that meets the specific needs of learners. By combining Learning Objects in different ways, higher-level learning goals can be met, and ultimately, entire courses could even be constructed (Johnson, 2003). 
Once all Learning Objects had been developed as described above, each Unit Coordinator then proceeded to develop their unit in a style which facilitated the best opportunities for student learning of the content. The following describes each of the three units and the use of the Learning Object environment to support student learning.

\section{BSA306 Electronic Commerce - Web-based learning objects, supported by face-to-face workshops}

While Learning Objects have been shown to provide opportunities for increased flexibility in student interaction and learning within a higher education setting, the importance of human experiences and workshop participation should not be undervalued. As noted by Johnson (2003) many forms of learning require kinds of human experiences. Although Learning Objects offer considerable promise for streamlining the development of learning materials, learning is a complex affair, and much work has yet to be done to devise effective ways of building learning tools that encourage collaboration, or discovery learning.

Web-based Learning Objects were integrated in this course as a mechanism by which theoretical content could be delivered while providing a practical learning focus in accordance with the need for greater flexibility in access and better recognition of student learning styles. The Unit Coordinator chose to adopt a Web-dependent model which uses the Learning Objects published on WebCT Vista as an integral part of the unit program to complement face-to-face teaching and print-based off-campus teaching.

As identified in Figure 5, within the context of this course, Learning Objectives were to be achieved by interaction with both the online Learning Objects and regular face to face workshops. The strong linkages between the objects and the workshops provided opportunities for deeper learning, with students able to learn theoretical content, interact with cases and undertake practical exercises before attending workshops designed to extend the practical application of the theoretical context.

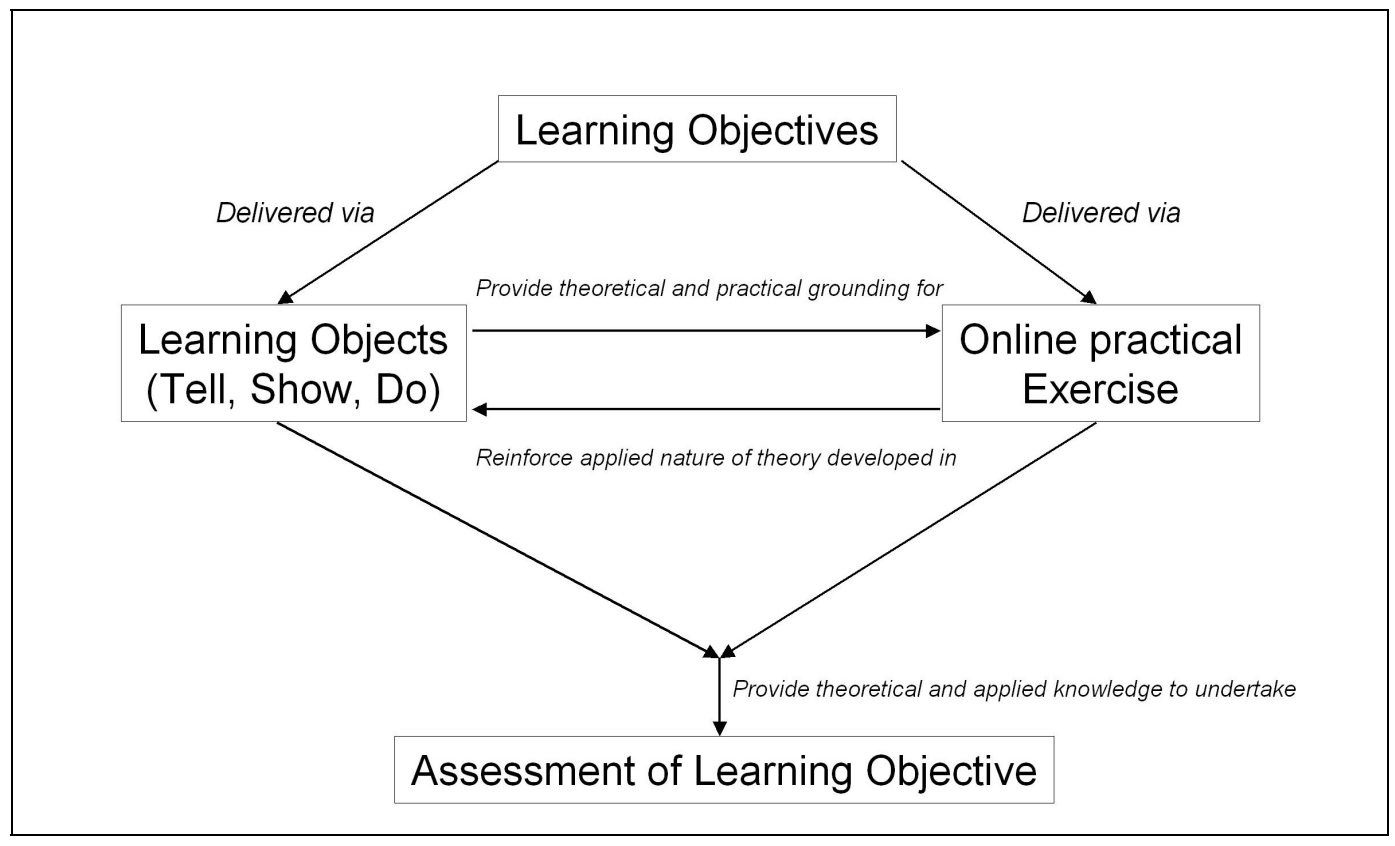

Figure 5: Course construction for BSA306 Electronic Commerce 


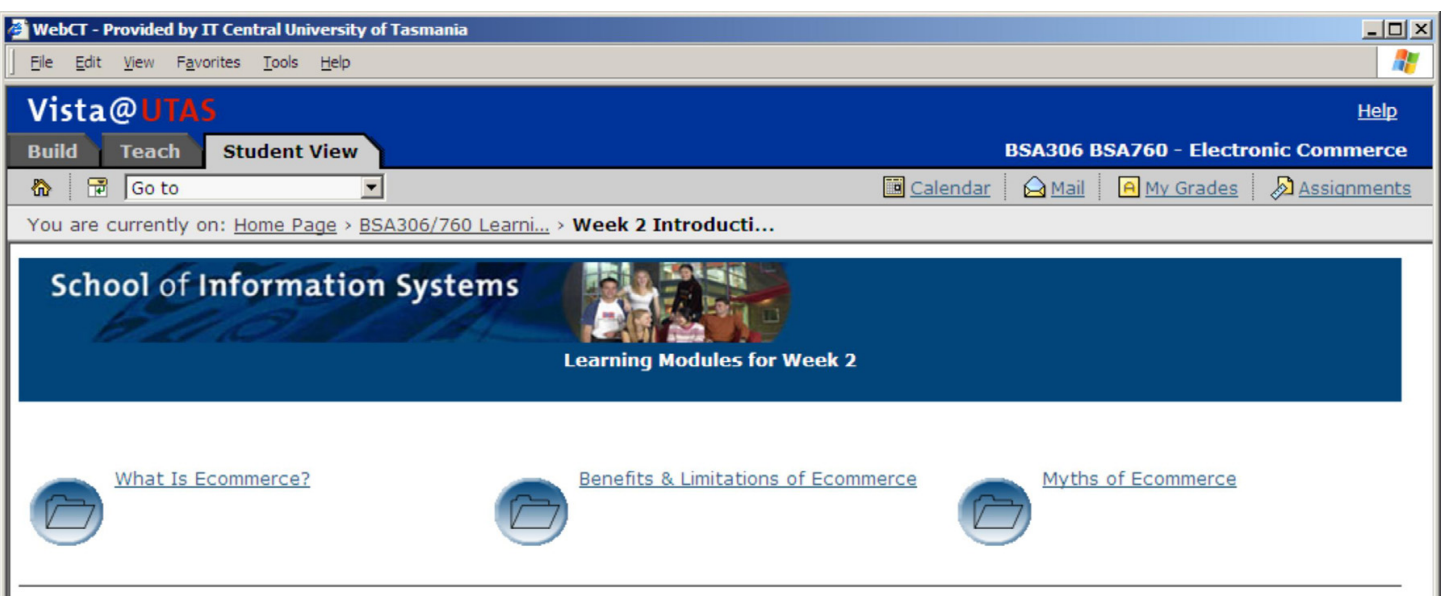

Figure 6: Learning Objects published on WebCT Vista

\section{BSA303 Management of Information Systems - Web-based learning objects and online discussions, supported by face-to-face workshops}

The basic web-dependent model of curriculum development as described above was also used as the basis for course development for BSA303 Management of Information Systems. However, in recognition of the fact that one of the most important features of online teaching is the capacity for students at different sites to interact with other students and with a lecturer or tutor via electronic bulletin boards or an electronic chat room, the coordinator of this unit augmented the course structure to include a discussion board facility. The purpose of the discussion board was to allow students to undertake group discussions on the Learning Object topics prior to attending face to face workshops.

This model of teaching and learning allowed theoretical content and critical analysis skills to be developed within the object environment, having these then supported by group discussions, which then led to workshop-based advanced analysis and practical application of a topic area.

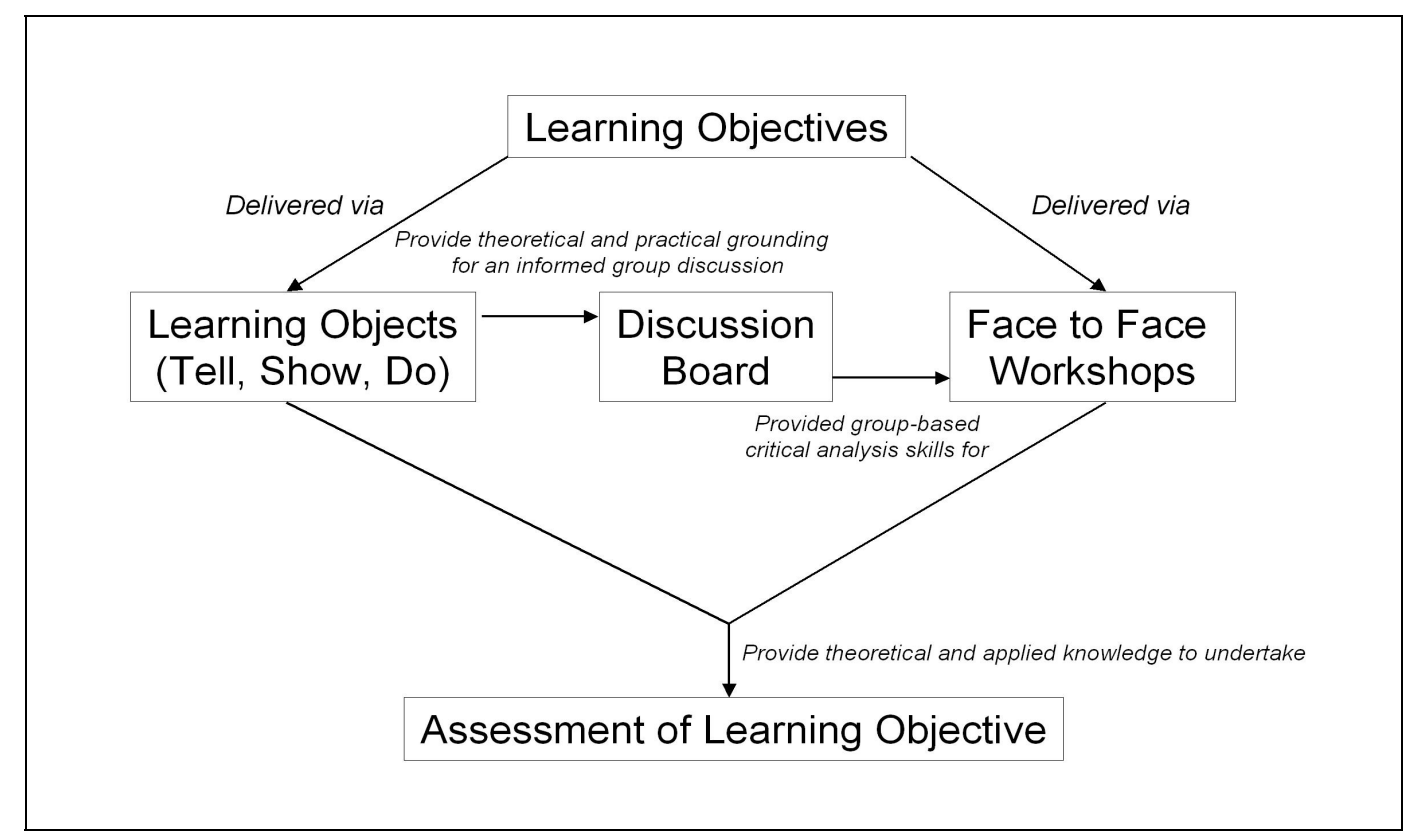

Figure 7: Course construction for BSA303 Management of Information Systems 


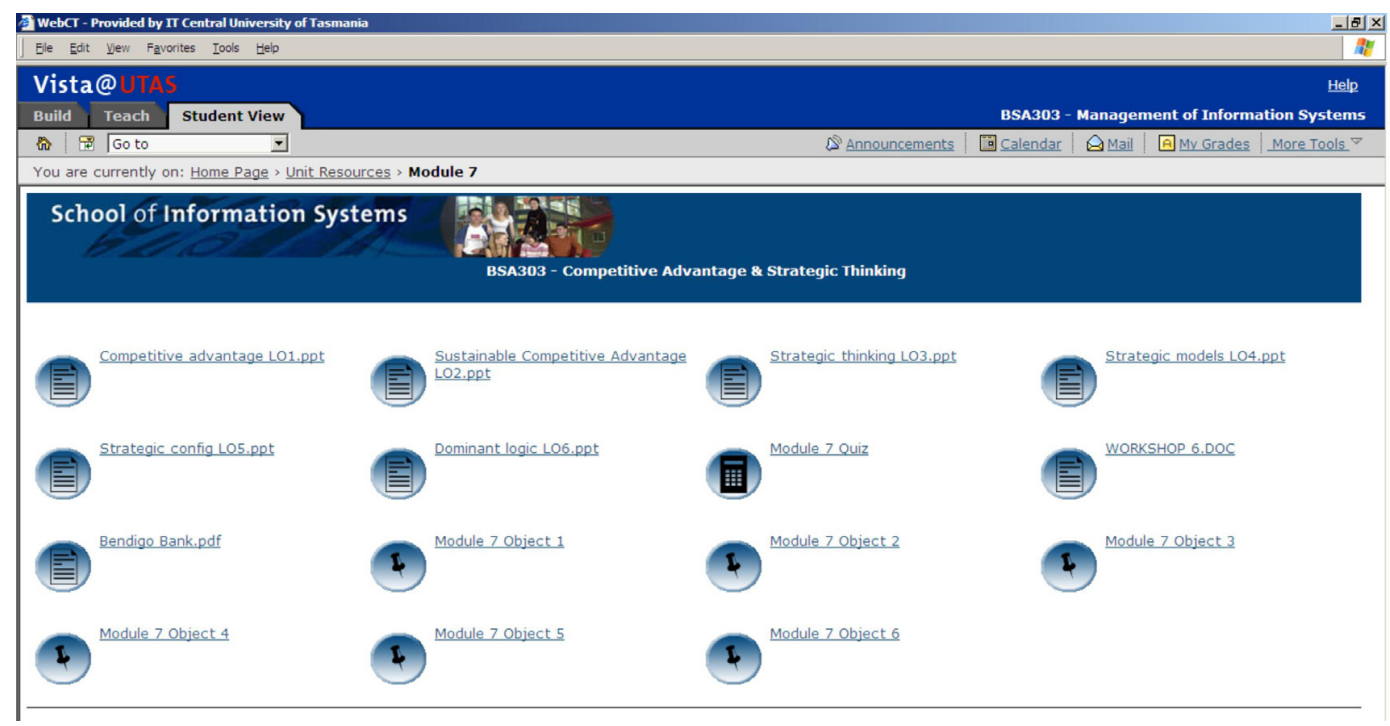

Figure 8: Learning Objects published on WebCT Vista

\section{BSA304 Decision Support Systems - Web-based learning objects, online discussions and online assessment.}

The third model of curriculum development with Learning Objects was undertaken by the coordinator of BSA304 Decision Support Systems. This course was developed as a fully-online course which used the web as the only formal and compulsory teaching and learning medium for the presentation of and access to content, communications between students and staff, and continuous assessment.

While the same style of Learning Object as developed in the previous two courses was employed in this course, those Learning Objects in BSA304 were used to provide theoretical and practical grounding for online practical exercises, rather than face-to-face workshops, as can be seen in Figure 9.

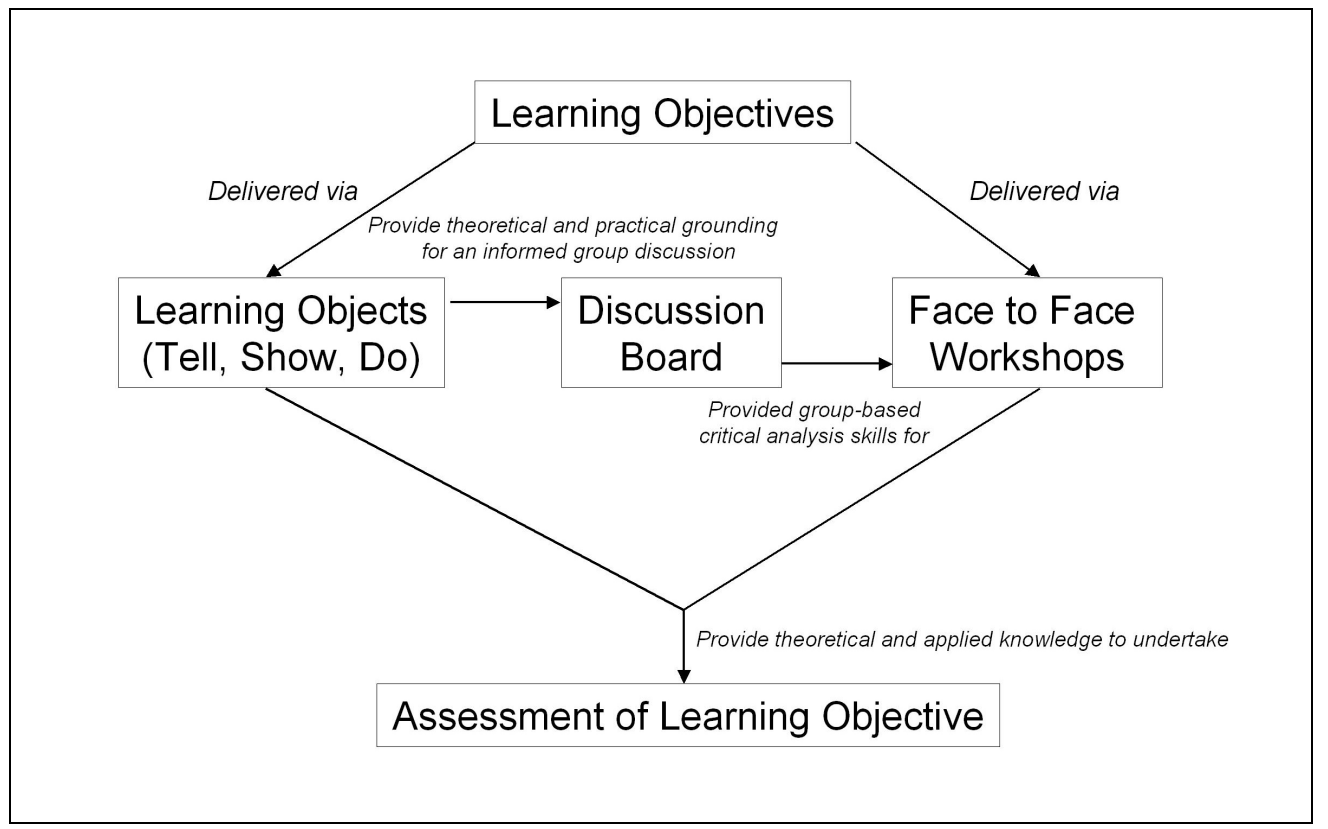

Figure 9: Course construction for BSA304 Decision Support Systems 


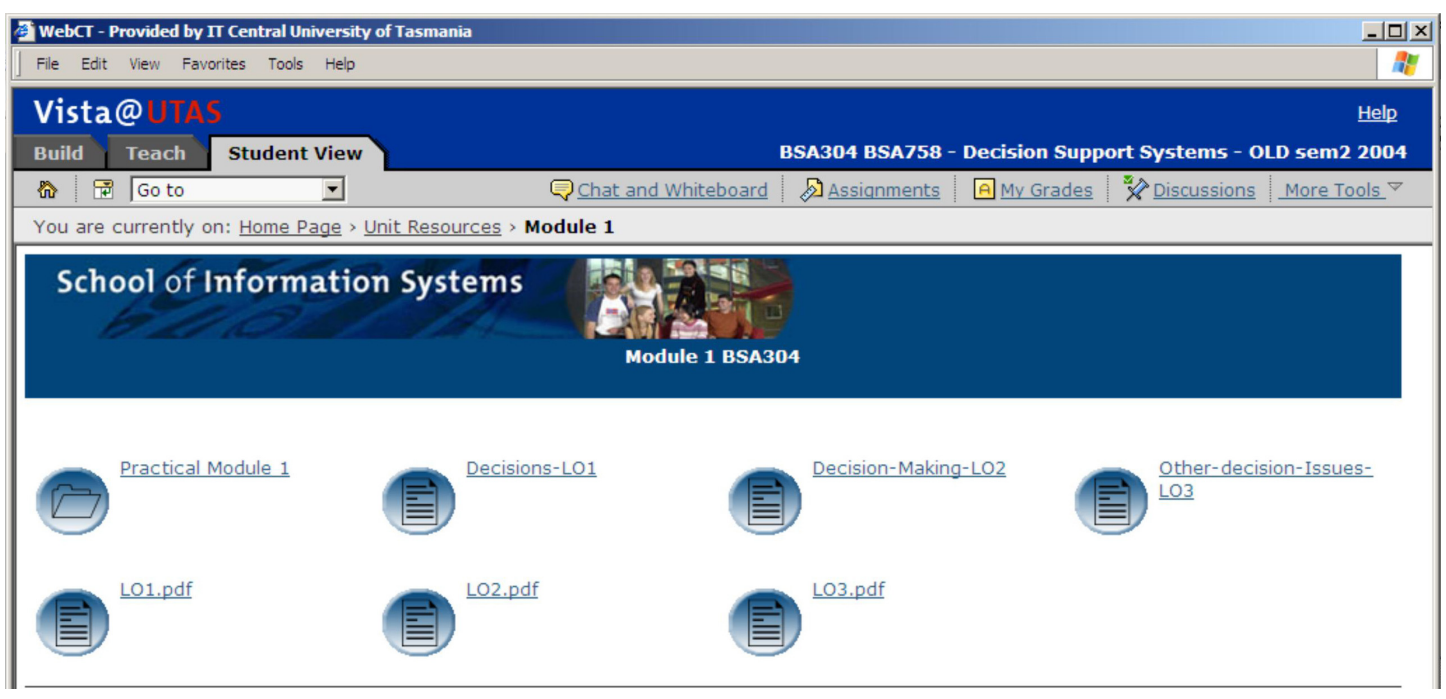

Figure 10: Learning Objects published on WebCT Vista

\section{How does this meet the Characteristics of Learning Objects?}

According to Wiley (2000), all Learning Objects have certain qualities. It is the difference in the degree to which they exhibit these qualities that makes one type of Learning Object different from another. Following Wiley's taxonomy of Learning Object types, those developed in this small-scale trial can be most closely aligned with the 'Combined-closed' type, that is, a small number of digital resources are combined at design time by the Learning Object's creator, whose constituent Learning Objects are not individually accessible for reuse from the combined closed learning object itself. The individual objects developed in this trial exhibit the following Learning Object characteristics (see Table 7):

Table 7: Learning Object characteristics

\begin{tabular}{|l|r|}
\hline Wiley's Learning Object Characteristics & Characteristics of the trial Learning Objects \\
\hline Number of individual elements combined & Few \\
\hline Types of objects contained & Single, combined-closed \\
\hline Reusable components objects & Yes, can be reused \\
\hline Common functions & Pre-designed instruction and/or practice \\
\hline Extra-object dependence & No \\
\hline Type of logic contained in object & None \\
\hline Potential for inter-contextual reuse & Medium \\
\hline Potential for intra-contextual reuse & Medium \\
\hline
\end{tabular}

While there are many types of Learning Objects, it is generally accepted that there are four goals of any Learning Object design. The following discussion provides insight into how the developments described in this paper fulfil the goals of reusability, interoperability, durability, and accessibility. 


\section{Reusability of the Learning Objects}

Learning Objects should be developed so that each object can be reusable across a variety of courses. Within the context of those developed at the School of Information Systems, all learning content was modularised into small units of instruction suitable for assembly and reassembly into a variety of courses as described in stage 4 above.

It was recognised that larger Learning Objects are typically harder to reuse, and smaller than objects save less work for those who reuse them. As a result each discrete topic for each course was developed into a 5-8 slide object. Specifically, this allowed a number of coordinators to make use of the same objects and to combine them into different course-specific contexts.

In addition, the decision to record each slide with a separate narration file was undertaken with the goal of reusability in mind. While the purpose of the objects was to allow all teaching staff to the same material, separate audio files allowed for customised narration of an object if this was deemed necessary by a particular instructor. Specially, the value of separate audio files became apparent when dealing with offshore teaching and learning. Separate audio files allowed instructors to include location-specific examples on a single slide, while not altering the general structure of the Object.

\section{Interoperability with Learning Management Systems}

The second goal of Learning Objects is that all instructional units should be able to interoperate with each other regardless of developer or learning management system. It was with this goal in mind that the developers chose to avoid a complex technological environment for their Object development. The use of widely-available development tools such as Microsoft ${ }^{\circledR}$ Office PowerPoint ${ }^{\circledR}$, Impatica for PowerPoint ${ }^{\mathrm{TM}}$, and the used of simple HTML files allowed for the easy development of new Objects by others not involved in the original trial program.

\section{Durability of the Objects}

The goal of durability suggests that units of instruction should be able to withstand ever evolving delivery and presentation technologies without becoming unusable. Given that the final product of the development process described previously was simple HTML files, these objects should not become unusable as a result of future technological developments. These objects will be durable across any delivery or presentation technology that allows for the incorporation of HTML files.

Within this project, durability also referred to the durability of the context contained with an object. Each object was developed in such a way that each small-scale object was neither timedependent nor context-dependent.

\section{Accessibility of the Objects}

In order to fulfil the goal of accessibility, learning content should be available anywhere, any time. The choice to publish the HTML-based Learning Objects into the University of Tasmania's learning management system ensured that all students who were enrolled in those courses detailed above would have 24 hour a day access to all learning content, regardless of their location.

\section{Issues with the Implementation of the Learning Object Approach}

As described previously, the purpose of Learning Objects is to allow a more flexible approach to teaching and learning, to support active learning strategies, and to reduce the redundancy often 
associated with content development. The following discussion provides insight into the experiences of the course developers/instructors and the students enrolled in the courses which this trial incorporated.

\section{Experiences of the Developers/Instructors}

On reflection, the process of Learning Object development and implementation was regarded as highly positive by all the developers and instructors. Specifically the two most substantial benefits were:

- It was the perception of all teaching staff involved in the program that as a result of the 'Tell-Show-Do' approach to the Learning Object development, students were better prepared for workshops and were more engaged in class discussions, given they had options of working through content material at their own pace and preparing for interactions more thoroughly than a face-to-face lecture would allow; and

- The reusability aspect of course content allowed developers to focus more of their time on developing innovative and engaging workshop activities, rather than developing and delivering theoretical content lectures.

While the use of Learning Objects was considered successful by the instructors, there were a number of two main disadvantages associated with the trial that was undertaken. Specifically:

- The amount of time for the initial development and preparation of the learning resources was substantial; and

- Managing new teaching processes, such as Web Sites and discussion boards increased the administrative load of instructors.

These negative issues however could be overcome by the provision of adequate educational and technological support for developers/instructors and a realistic workload allocation for so-called 'non-lecturing' time.

\section{Experiences of the Students}

At the commencement of the trial implementation of the new course structures, students expressed some reluctance when considering the introduction of Learning Objects into their courses. The main negative perception was associated with the increase in responsibly they would have for their own learning progress, since they were no longer expected to attend scheduled face-to-face lectures.

The following section provides some quantitative and qualitative feedback obtained from students across the three courses included in this trial. A formal questionnaire to elicit student responses to Teaching and Learning was provided to students, with a total of 172 students responding to the questionnaire. As can be seen, there were generally positive responses to the introduction of the Learning Object structure, despite the initial negative perceptions.

When specially asked to respond to three statements on the introduction of Learning Objects in a survey of Student Evaluation of Teaching and Learning, the following responses were recorded: 


\section{Development and Implementation of Learning Objects}

Statement:

"The use of Learning Objects was an improvement to normal lectures"

Response:

\begin{tabular}{|l|l|l|l|l|l|}
\hline $\begin{array}{l}\text { Strongly } \\
\text { Disagree }\end{array}$ & Disagree & Neutral & Agree & $\begin{array}{l}\text { Strongly } \\
\text { Agree }\end{array}$ & No Answer \\
\hline $10.87 \%$ & $10.87 \%$ & $20.65 \%$ & $39.13 \%$ & $15.22 \%$ & $3.26 \%$ \\
\hline
\end{tabular}

Statement:

"The flexibility of study in this unit better suited my approaches to or style of learning"

Response:

\begin{tabular}{|l|l|l|l|l|l|}
\hline $\begin{array}{l}\text { Strongly } \\
\text { Disagree }\end{array}$ & Disagree & Neutral & Agree & $\begin{array}{l}\text { Strongly } \\
\text { Agree }\end{array}$ & No Answer \\
\hline $6.52 \%$ & $6.52 \%$ & $17.39 \%$ & $41.30 \%$ & $25 \%$ & $3.26 \%$ \\
\hline
\end{tabular}

Statement:

"I have learnt to think critically"

Response:

\begin{tabular}{|l|l|l|l|l|l|}
\hline $\begin{array}{l}\text { Strongly } \\
\text { Disagree }\end{array}$ & Disagree & Neutral & Agree & $\begin{array}{l}\text { Strongly } \\
\text { Agree }\end{array}$ & No Answer \\
\hline $1.09 \%$ & $3.26 \%$ & $20.65 \%$ & $58.7 \%$ & $13.04 \%$ & $3.26 \%$ \\
\hline
\end{tabular}

The following statements were made by students as unsolicited comments related to the use of Learning Objects throughout the courses:

"I liked the Learning Objects very much. This format worked well and was very flexible. Way better that the lecture format!"

"The Learning Objects were good, and allowed you to do them in your own time"

"The practical nature of the Objects is great! Real life applications that prepare students well for their working life"

"The slides and their narrated forms are excellent for this type of work"

"I liked the online delivery as I work"

"Online lectures were very useful"

"Flexible learning techniques - the workshops were very good and interactive and relevant to the topics"

"Flexible learning and straight-forward workshops assisted the main assignments" 


\section{Conclusion}

This paper has described a simple yet effective approach to the process of Learning Object design and construction undertaken in three third-year units at the School of Information Systems, University of Tasmania.

The driver for the introduction of Learning Objects was an identification of the changing needs of University students, and the resource redundancies involved with traditional course development processes.

An important point to make is that the increase in flexibility allowed by the development of these Learning Objects was not about replacing the human dimension of the teaching and learning experience, but about enhancing the face-to-face time spent between students and instructors. In fact, the main benefit of the Learning Object development project identified in this paper was the apparent enhancement of the quality of the human interaction due to the fact that the time when students and teachers interact was not wasted by transmitting information which could be more effectively transmitted by other means.

This paper provided examples of how the four principles of Learning Objects: reusability, interoperability, durability, and accessibility; were achieved under three different models of curriculum development. Challenges for the future developments of Learning Objects within this University environment will include: the development of a wider range of discrete topic objects to extend the pool of content available to instructors; the development of a Learning Object repository for ease of storage and access to the Objects for all instructors; and an investigation of a more dynamic, individualised, and student-managed curriculum development process.

\section{References}

Clyde, L. A. (2004). Digital learning objects. Teacher Librarian, 31(4), 55-58.

Commerce. (2003). Major faculty teaching project proposal: 2003. [Internal Faculty Report], University of Tasmania. [This was developed by a team in the faculty, and as a result, has no named authors. The document itself is no longer available to the public via the web site, but would be available on application to the faculty.]

EDUCAUSE (2005). Learning objects. Retrieved from http://www.educause.edu/contnet.asp?page id $=2601 \& b h c p=1$

Flexible Education Unit. (2002). Teaching and learning development plan 2003-2005, University of Tasmania. Retrieved from http://www.utas.edu.au/tl/reports.html

Freeman, V. S. (2004). Learning objects in microbiology: A new resource. Clinical Laboratory Science, $17(2), 80$.

Gallenson, A., Heins, J., \& Heins, T. (2002). Macromedia MX: Creating learning objects. [Macromedia white paper]. Macromedia Inc. Available at http://download.macromedia.com/pub/elearning/objects/mx_creating_lo.pdf

Hiddink, G. (2001). Solving reusability problems of online learning materials. Campus-wide Information Systems, 18(4), 146-153.

Johnson, L. F. (2003). Elusive vision: Challenges impeding the learning object economy. [Macromedia white paper]. Macromedia Inc.

Johnston, S. (2001). Flexible teaching and learning at the University of Tasmania: Some strategies to move us forward. University of Tasmania [internal paper].

Orrill, C. H. (2000). Learning objects to support inquiry-based online learning. In D. A. Wiley (Ed.), The instructional use of learning objects: Online version. Retrieved from http://reusability.org/read/chapters/orrill.doc 
Parrish, P. E. (2004). The trouble with learning objects. Educational Technology, Research and Development, 52(1), 49-68.

Polsani, P. R. (2003). Use and abuse of reusable learning objects. Journal of Digital Information, 3(4).

Wiley, D. A. (2000). Connecting learning objects to instructional design theory: A definition, a metaphor, and a taxonomy. In D. A. Wiley (Ed.), The instructional use of learning objects: Online version. Retrieved from http://reusability.org/read/chapters/wiley.doc

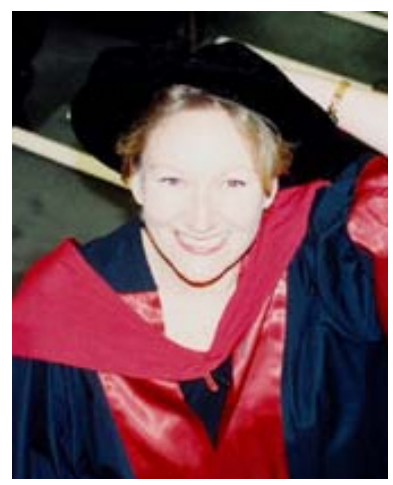

\section{Biographies}

Dr. Kristy de Salas is a Lecturer in the School of Information Systems, University of Tasmania, Australia. Kristy coordinates University courses in Web Management, Electronic Commerce, Research Methods and Project Management and researches in the domains of Teaching and Learning, Application Service Providers and IS Strategy and Governance. Kristy has received awards for innovative teaching, has held positions on numerous Teaching and Learning committees and has presented her work in the Learning Objects domain throughout Australia.

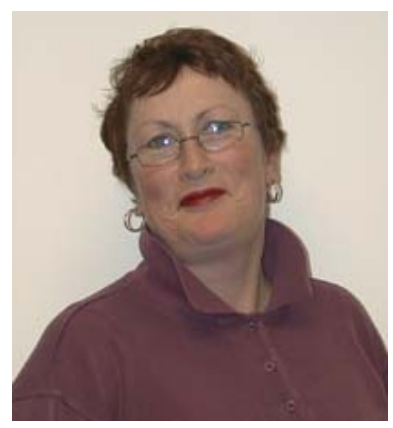

Ms Leonie Ellis is a Lecturer in the School of Information Systems, University of Tasmania, Australia. Leonie coordinates University courses in Management of Information Systems, Decision Support Systems and Research Methods and researches in the domains of Teaching and Learning and Change Management. Leonie has held positions on numerous Teaching and Learning committees and currently serves as a University Teaching Catalyst and has presented her work in the Learning Objects domain throughout Australia. 